\title{
STUDI PROSEDUR PENILAIAN DOMAIN AFEKTIF OLEH GURU PAI DI SMP NEGERI 2 BANDUNG DAN SMP SALMAN AL-FARISI BANDUNG
}

\author{
Nur Anis Saila Pajrin*, Abas Asyafah, dan Saepul Anwar \\ Universitas Pendidikan Indonesia, Bandung \\ *E-mail:nuranissailapajrin@student.upi.edu
}

\begin{abstract}
This article examines the procedure for evaluating the process and learning outcomes of Islamic Religious Education (IRE/PAI) in the affective aspect. In IRE/PAI, the assessment of affective aspect is still a problem. In fact, there are many obstacles in its application. This research uses a qualitative approach with descriptive methods. Data collection uses observation, interview, documentation, and triangulation techniques. Analysis of research data is carried out in the form of data reduction, data display, and verification. Based on the results of the study, it was found that the stage of the preparation of attitude assessment instruments in schools was in accordance with the established guidelines, but related to the design of the grid and analyzing the quality of the instrument was not optimally implemented. Then the implementation stage of the attitude assessment was generally applied according to the guidelines, although there were still obstacles that were not in accordance with the plan. Finally, the results stage of the attitude assessment process has been carried out according to the guidelines, but in terms of time control and objective assessment decisions need to be optimized.
\end{abstract}

Keywords: Assessment, Affective Domain, Islamic Religius Education.

\begin{abstract}
Abstrak. Artikel ini mengkaji prosedur penilaian proses dan hasil belajar Pendidikan Agama Islam (PAI) dalam aspek afektif. Dalam PAI, penilaian aspek afektif masib menjadi permasalahan. Pada kenyataannya, terdapat banyak kendala dalam penerapannya. Penelitian ini menggunakan pendekatan kualitatif dengan metode deskriptif. Pengumpulan data menggunakan teknik-teknik observasi, wawancara, dokumentasi dan triangulasi. Analisis data penelitian dilakukan dalam bentuk reduksi data, display data, dan verifikasi. Berdasarkan hasil penelitian, ditemukan bahwa tahap penyusunan instrumen penilaian sikap di sekolab sudah sesuai dengan pedoman yang ditetapkan, namun terkait perancangan kisi-kisi dan penganalisaan kualitas instrumen belum optimal terlaksanakan. Kemudian tahap pelaksanaan penilaian sikap, secara umum teraplikasikan sudah sesuai panduan, meskipun masih terdapat kendala yang tidak sesuai dengan rencana. Terakbir, tahap hasil dari proses penilaian sikeap, sudah terlaksana sesuai pedoman, namun dalam hal pengendalian waktu dan keputusan penilaian yang objektif perlu dioptimalkan lagi.
\end{abstract}

Kata Kunci : Penilaian, Domain Afektif, Pendidikan Agama Islam

TARBAWY: Indonesian Journal of Islamic Education - Vol. 6 No. 2 (2019) |157 


\section{PENDAHULUAN}

Guru profesional adalah guru yang melaksanakan tugas keguruan dengan kemampuan tinggi (profesiensi) sebagai sumber kehidupan. Dalam menjalankan kewenangan profesionalnya, guru dituntut memiliki keanekaragaman kecakapan (competencies) psikologis yang meliputi kompetensi kognitif (kecakapan ranah cipta), kompetensi afektif (kecakapan ranah rasa), dan kecakapan psikomotor (kecakapan ranah karsa) (Yusutria, 2017, hal. 41-42).

Dalam Undang-Undang Nomor 20 Tahun 2003 pasal 39 ayat 2 tentang Sistem Pendidikan Nasional menyatakan bahwa pendidik adalah tenaga professional yang bertugas merencanakan dan melaksanakan proses pembelajaran, menilai hasil pembelajaran, melakukan bimbingan dan pelatihan, serta melakukan penelitian dan pengabdian kepada masyarakat, terutama bagi pendidik pada perguruan tinggi. Salah satu tugas menjadi guru yang professional adalah melakukan penilaian hasil pembelajaran.

Berdasarkan landasan yuridis tersebut, penilaian merupakan salah satu kompetensi yang harus dimiliki oleh seorang guru (Rini, 2014, hal. 1). Dalam UU No. 20 Tahun 2003 pasal 63 ayat (1) dinyatakan bahwa guru atau pendidik merupakan salah satu unsur yang diamanatkan untuk melakukan penilaian pendidikan pada jenjang pendidikan dasar dan menengah. Dalam PP No. 32 Tahun 2013 tentang Perubahan Atas Peraturan Pemerintah Nomor 19 Tahun 2005 tentang Standar Nasional Pendidikan Bab I tentang Ketentuan Umum pasal 1 ayat (24) dinyatakan bahwa "penilaian adalah proses pengumpulan dan pengolahan informasi untuk mengukur hasil belajar peserta didik". Dalam pandangan Arifin (2017, hal. 4), penilaian yang dilakukan guru merupakan suatu proses yang sistematis dan berkesinambungan.

Dapat disimpulkan bahwa penilaian merupakan sebuah proses yang sistematis yang dilaksanakan untuk mengumpulkan informasi terkait dengan proses dan hasil belajar peserta didik dengan pertimbangan dan kriteria tertentu, sehingga akan diketahui perkembangan peserta didik selama melakukan kegiatan belajar. Maka melaksanakan penilaian atau evaluasi merupakan kemampuan yang harus dimiliki oleh seorang guru. Dengan hasil penilaian tersebut, seorang guru atau pendidik bisa menjadikannya sebagai bahan pertimbangan dalam membuat keputusan yang berkaitan dengan kegiatan pembelajaran (Anwar \& Fakhruddin, 2016, hal. 139-141).

Penilaian pembelajaran itu penting dilakukan agar siswa mengetahui dan selalu meningkatkan potensi yang ada pada dirinya. Penilaian pembelajaran pun tidak hanya ditekankan pada penilaian kognitif dan psikomotorik saja, tetapi juga penilaian ranah afektif, karena keberhasilan pembelajaran pada ranah kognitif dan psikomotor pun sangat ditentukan oleh kondisi sikap siswa (Wicaksono, Pamuji, Muhardjito, \& Harsiati, 2016, hal. 46). Menurut Suyanto (2010, hal. 159), pengabaian ranah afektif merugikan perkembangan peserta didik baik secara individual maupun masyarakat secara keseluruhan.

Tendensi yang ada ialah peserta didik menjadi tahu banyak tentang sesuatu, namun kurang memiliki sikap, minat, sistem nilai maupun apresiasi positif terhadap apa yang mereka ketahui. Melihat tahapan yang diajukan Kratwohl (Sudijono, 2016, hal. 54), maka untuk mengukur ranah afektif memang memerlukan waktu yang relatif lebih lama. Hal ini disebabkan ranah afektif bukan hanya sekedar mementingkan penguasaan materi kognisi ataupun 
keterampilan, tetapi juga menginginkan terinternalisasinya nilai-nilai yang telah diajarkan dalam kehidupan sehari-hari peserta didik (Kusumawati, 2015, hal. 113).

Sebagaimana suatu penelitian menyatakan bahwa berkaitan dengan penilaian pembelajaran, ada sekitar 14 responden guru PAI yang sama sekali tidak memiliki buku catatan perilaku siswa. Penyebabnya rata-rata karena tidak disediakan oleh pihak sekolah dan terlalu banyak kelas yang dibina, sehingga kalau harus mengisi buku catatan perilaku siswa, mereka merasa terlalu banyak pekerjaan yang harus dilakukan. Padahal catatan buku perilaku siswa ini sangat diperlukan untuk dimiliki dan dilakukan oleh guru PAI sehubungan dengan karakteristik mata pelajaran PAI yang lebih menekankan pada aspek afektif atau akhlak. Sementara itu sisa responden sebanyak 81 orang menyatakan memiliki buku catatan perilaku siswa, itupun kebanyakan atas inisiatif sendiri. Dalam buku tersebut mereka mendokumentasikan catatan siswa seputar perilaku, pelanggaran terhadap aturan, praktik ibadah dan aktivitas siswa di ekskul keagamaan (Anwar \& Fakhruddin, 2016, hal. 150-151).

Bidang afektif pada dasarnya berkenaan dengan sikap dan nilai. Sikap seseorang dapat diramalkan perubahanperubahannya bila seseorang telah menguasai bidang kognitif tingkat tinggi. Tipe hasil belajar afektif tampak pada siswa dalam berbagai tingkah laku, seperti atensi (perhatian) terhadap pelajaran, disiplin, motivasi belajar yang tinggi, menghargai guru dan teman sekelas, kebiasaan belajar, dan lain sebagainya. Akan tetapi, hasil belajar bidang afektif kurang mendapatkan perhatian dari guru karena guru lebih banyak memberikan tekanan pada bidang kognitif. Seharusnya, sekalipun mata pelajaran berisi bidang kognitif, bidang afektif harus nampak dalam proses belajar dan hasil belajar yang telah dicapai. Oleh karena itu, guru harus menentukan ranah afektif, selain kognitif dalam pembelajaran agar siswa tidak sekadar memahami dan menghafal materi yang diajarkan, tetapi juga mengaplikasikan nilai- nilai mata pelajaran yang diajarkan (Betwan, 2019, hal. 55-56).

Maka didasarkan realita tersebut didapatkan sebuah kesenjangan berupa tuntutan penilaian pembelajaran dalam semua ranah pembelajaran (penilaian autentik) oleh guru profesional, namun kenyataan secara umum yang terlaksana di lapangan adalah penilaian ranah kognitif saja sehingga perlu disosialisasikan lagi pentingnya ranah afektif untuk disertakan pula, khususnya dalam mata pelajaran PAI yang memerlukan pengalaman nyata pada setiap pemahaman materinya dalam kehidupan sehari-hari. Berdasarkan kesenjangan yang ditemukan, perlu dilakukan penelitian untuk mengukur sejauh mana aspek afektif pada penilaian pembelajaran mata pelajaran PAI di sekolah terlaksana.

Diperkuat dengan hasil-hasil penelitian sejenis yang juga dilakukan sebelumnya seperti hasil penelitian di SMPN 5 Batusangkar yang menyatakan guru PAIBP telah merencanakan, melaksanakan, dan melaporkan hasil penilaian sikap spritual dan sikap sosial sesuai dengan pedoman untuk pengambilan keputusan selanjutnya (Aulia, 2018, hal. 84-85) dan penelitian di SD Negeri 1 Cendana dan SD Negeri 1 Kembaran Kulon mengenai penilaian autentik ranah sikap di SD Piloting Project Kurikulum 2013 Kabupaten Purbalingga (Zen, 2017, hal. 179) yang nyatanya membutuhkan tindak lanjut, maka peneliti bermaksud melanjutkan penelitian tersebut dengan objek penelitian yang berbeda supaya diperoleh hasil lebih luas dan mendalam. 
Berdasarkan hasil pra survey di lapangan, peneliti berasumsi bahwa wujud dari pelaksanaan prosedur penilaian pembelajaran yang baik, implementasi di lapangannya bisa dilihat dari sistem yang dijalankan oleh sekolahsekolah unggulan. Maka peneliti memilih perwakilan dari setiap sekolah negeri dan swasta unggulan untuk dijadikan contoh bagaimana pelaksanaan prosedur penilaian pembelajaran yang sesuai dengan peraturan perundang-undangan. Untuk membuktikan asumsi tersebut, maka perlu diteliti.

\section{METODE PENELITIAN}

Penelitian ini menggunakan pendekatan kualitatif dengan metode deskriptif. Penelitian kualitatif diartikan sebagai suatu penelitian yang ditujukan untuk mendeksripsikan dan menganalisis fenomena, peristiwa, aktivitas sosial, sikap, kepercayaan, persepsi, pemikiran orang secara individual maupun kelompok (Sukmadinata, 2011, hal. 60). Metode penelitian deskriptif digunakan, karena pada dasarnya tujuan dari penelitian ini adalah untuk memperoleh gambaran mengenai prosedur penilaian pembelajaran PAI domain afektif di beberapa SMP unggulan di Kota Bandung.

Lokasi penelitian ini bertempat di SMP Negeri 2 Bandung yang berlokasi di Jl. Sumatera No. 42 Bandung dan SMP Salman Al-Farisi Bandung yang berlokasi di Jl. Tubagus Ismail VIII Atas, Bandung. Ada beberapa orang yang menjadi partisipan dalam penelitian ini, antara lain: (1) Wakil Kepala Sekolah Bidang Kurikulum; (2) Wakil Kepala Sekolah Bidang Kesiswaan; (3) Guru mata pelajaran PAI yang bersangkutan; (4) Wali Kelas; (5) Guru Bimbingan dan Konseling; dan (6) Siswa Kelas Ajar Guru PAI yang bersangkutan.

Penelitian ini peneliti menggunakan tiga teknik pengumpulan data, yaitu interview (wawancara), observasi dan studi dokumentasi. Terkait wawancara, jenis wawancara yang dilakukan yaitu wawancara terstruktur, yakni ditandai dengan adanya pertanyaan yang telah disediakan untuk dijawab oleh responden dengan dengan bekal pedoman wawancara yang telah dipersiapkan. Peneliti mewawancarai pihak-pihak yang menjadi partisipan/informan dalam penelitian ini, seperti wawancara kepada Wakil Kepala Sekolah Bidang Kurikulum, Wakil Kepala Sekolah Bidang Kesiswaan, Guru PAI yang bersangkutan, Wali Kelas, Guru BK dan Siswa. Selain itu, dilakukan pula wawancara tidak terstruktur, yakni saat peneliti akan bebas melakukan wawancara sewaktu-waktu, ketika ada data yang kurang dan perlu mempertanyakan kembali atas jawaban yang tidak dimengerti oleh peneliti. Terkait observasi, yang dilakukan peneliti adalah mengamati guru PAI dalam melaksanakan prosedur penilaian domain afektif pada saat mengajar mata pelajaran PAI di kelas. Teknisnya yakni pada saat berlangsungnya mata pelajaran PAI di kelas, peneliti mengamati dengan berbekal pedoman observasi yang telah dibuat. Observasi dilakukan hanya di SMP Negeri 2 Bandung saja, karena di SMP Salman Al-Farisi Bandung tidak diizinkan. Dan terkait studi dokumentasi, peneliti meminta dokumen-dokumen yang berkaitan dengan prosedur penilaian domain afektif mata pelajaran PAI kepada Bapak/Ibu guru PAI di SMP Negeri 2 Bandung dan SMP Salman Al-Farisi Bandung, meliputi data sekolah, dokumen-dokumen terkait penyusunan instrumen penilaian domain afektif, dokumen-dokumen terkait pelaksanaan penilaian domain afektif, dan dokumen-dokumen terkait hasil pelaksanaan penilaian domain afektif pada mata pelajaran PAI. 


\section{HASIL PENELITIAN DAN PEMBAHASAN}

Bangunan sekolah di jalan Sumatera 42 telah berdiri kokoh pada tahun 1913. Sejak itu gedung sekolah memiliki warna khas hijau daun sebagai lambang penyejuk hati para penghuninya dan kesuburan tanah pijakannya. Secara historis pada tahun 1930 sekolah ini merupakan sekolah Belanda MULO (sederajat dengan SMP) di jalan Papandayan ( sekarang jalan Gatot Subroto ), kemudian pindah ke jalan Babakan ( sekarang jalan H. Yakub / SMPN 6 Bandung ). Pada tahun 1948 berganti nama menjadi SMP Nomor 2, mengikuti nomor SMP yang sudah ada di jalan Ksatrian yaitu SMPN 1 Bandung. Kemudian pada tahun 1950 SMPN 2 ini menempati gedung ELS (Europersche Lagere School) berdasarkan Surat Keputusan Pendidikan dan Kebudayaan Nomor 9033 / SK / B / 11 Oktober 1950 (Dok.1A).

Pada tahun 2002 SMP Negeri 2 Bandung dipercaya menjadi minim piloting kurikulum berbasis kompetensi, kemudian pada tahun 2004 SMPN 2 Bandung resmi sebagai sekolah standar nasional dan akhirnya pada tahun 2008 ditunjuk oleh Kementerian Pendidikan Nasional Direktorat Jenderal Manajemen Pendidikan Dasar dan Menengah sebagai Rintisan Sekolah Bertaraf Internasional (RSBI) dengan SK 1446/C3/DS/2008. Pada tahun 2012 Kementerian Pendidikan dan Kebudayaan (Kemendikbud) mencabut peraturan menteri pendidikan nasional (permendiknas) Nomor 78 Tahun 2009 tentang Penyelenggaraan Sekolah Bertaraf Internasional (SBI)/Rintisan SBI. Pencabutan itu sebagai dampak dari putusan Mahkamah Konstitusi (MK) yang menghapuskan status sekolah Internasional. Kemudian pada tahun 2013, SMP Negeri 2 Bandung ditunjuk pemerintah melalui Kemendikbud sebagai salah satu sekolah di Indonesia atau enam sekolah negeri di kota Bandung yang pertama menerapkan kurikulum 2013. Sejak tahun 2015, selain sebagai sekolah rujukan nasional dan sekolah berbudaya lingkungan nasional, juga sebagai sekolah berbudaya dan religi, serta sebagai sekolah ramah anak (Dok.1A). Semua rangkaian prestasi ini bisa terwujud, tidak lain dikarenakan sekolah berpegang teguh pada visi dan misi yang dibuatnya. Dengan visi dan misi yang dijalankan yakni sebagai "Sekolah Berkarakter, Berprestasi Nasional dan Internasional", maka segala bentuk program sekolah yang dijalankan adalah untuk mendukung keselarasan dengan visi misi tersebut. Dari rangkaian jejak sejarah tersebut, SMP Negeri 2 Bandung terbukti dikategorikan sebagai sekolah unggulan dikarenakan banyak dijadikan sebagai contoh dalam berbagai hal bagi sekolah lainnya. Untuk itu, sekolah ini sangat patut dijadikan sebagai tempat penelitian untuk melihat contoh bagaimana implementasi penilaian sikap dilakukan.

\section{SMP Salman Al-Farisi Bandung}

SMP Salman Al-Farisi merupakan sekolah menengah tingkat pertama di Bandung yang menerapkan sistem pembelajaran full day. Didirikan dan mulai beroperasi pada bulan Juli tahun pelajaran 1997/1998. Berbagai prestasi telah diperoleh baik akademik maupun non akademik mulai dari tingkat kota, provinsi, nasional sampai tingkat internasional. Di antara rangkaian prestasi yang didapatkan, prestasi akademik tertinggi SMP Salman Al-Farisi diraih pada tahun 2013 di Olympiade Sains Nasional dengan meraih medali emas untuk mata pelajaran IPS dan mewakili Indonesia di tingkat Internasional dalam ajang National Geograpyc World Championship (NGWC) di Rusia (Dok.1B). Prestasi non akademik telah berhasil diperoleh mulai cabang olahraga dan seni, bela diri dan 
kreativitas. Di antara rangkaian prestasi yang didapatkan, prestasi tertinggi untuk non akademik yang diraih adalah bidang kreativitas yaitu pembuatan film ajang Kid Witness News untuk tingkat Nasional dan berhak mewakili Indonesia di ajang regional Asia Pasific yang berhasil meraih kategori Best Music di Singapura pada tahun 2014 (Dok.1B).

Semua rangkaian prestasi ini bisa terwujud, tidak lain dikarenakan sekolah berpegang teguh pada visi dan misi yang dibuatnya. Dengan visi dan misi yang dijalankan yakni sebagai "Menjadi Lembaga Pendidikan yang Mampu Mengembangkan dan Menghasilkan Generasi Muslim yang Siap menjadi Khalifah - fii Ardi yang rabmatan lil alamin.", maka segala bentuk program sekolah yang dijalankan adalah untuk mendukung keselarasan dengan visi misi tersebut, yakni untuk membangun dan menyelenggarakan sistem pendidikan komprehensif yang menyiapkan lulusannya untuk menjadi generasi muslim yang berkemampuan Khalifah fii Ardi yang rabmatan lil alamin. Dari rangkaian jejak sejarah tersebut, SMP Salman Al-Farisi Bandung terbukti dikategorikan sebagai sekolah swasta unggulan dikarenakan banyak dijadikan sebagai contoh dalam berbagai hal bagi sekolah lainnya. Untuk itu, sekolah ini sangat patut dijadikan sebagai tempat penelitian untuk melihat contoh bagaimana implementasi penilaian sikap dilakukan.

Selanjutnya, akan dibahas mengenai studi realitas prosedur penilaian domain afektif oleh guru PAI. Menurut KBBI, studi adalah penelitian ilmiah; kajian; telaahan. Sedangkan realitas adalah kenyataan. Jadi, studi realitas adalah suatu kajian/telaahan tentang sebuah kenyataan. Prosedur adalah tahap kegiatan untuk menyelesaikan suatu aktivitas; metode langkah demi langkah secara pasti dalam memecahkan suatu masalah (Kamus
Besar Bahasa Indonesia, n.d.). Sehingga prosedur bisa diartikan sebagai suatu tahapan dalam melaksanakan sebuah aktivitas/kegiatan. Terkait penilaian seperti halnya menurut Permendikbud No. 23 Tahun 2016, bahwa penilaian adalah proses pengumpulan dan pengolahan informasi untuk mengukur pencapaian hasil belajar peserta didik. Hal yang diukur beragam kompetensi, seperti yang dijelaskan di dalam Kurikulum 2013.

Di antara kompetensi tersebut, salah satu yang membutuhkan perhatian penting adalah domain afektif. Domain afektif adalah istilah lain dari ranah sikap. Ranah afektif adalah ranah yang berkaitan dengan sikap dan nilai. Sikap adalah salah satu istilah bidang psikologi yang berhubungan dengan persepsi dan tingkah laku (Depag RI, hal. 3). Istilah sikap dalam bahasa Inggris disebut attitude. Attitude adalah suatu cara bereaksi terhadap suatu perangsang atau suatu kecenderungan untuk bereaksi terhadap suatu perangsang atau situasi yang dihadapi (Mantau, 2009, hal. 116117). Maka terkait penilaian sikap di sekolah, bisa diartikan sebagai sebuah kegiatan untuk mengetahui perilaku spiritual dan sosial peserta didik yang dapat diamati dalam kehidupan seharihari, baik di dalam maupun di luar kelas sebagai hasil pendidikan (Kementerian Pendidikan dan Kebudayaan, 2017, hal. 31).

Kegiatan penilaian sikap, salah satunya dilakukan oleh guru PAI. Guru PAI adalah pendidik profesional dengan tugas utama mendidik, mengajar, membimbing, mengarahkan, melatih, menilai, dan mengevaluasi peserta didik pada pendidikan anak usia dini jalur pendidikan formal, pendidikan dasar dan pendidikan menengah (Undang-Undang No 14 tahun 2005) pada mata pelajaran Pendidikan Agama Islam. Pendidikan Agama Islam bisa diartikan sebagai pendidikan yang memberikan

TARBAWY: Indonesian Journal of Islamic Education - Vol. 6 No. 2 (2019) | 162 
pengetahuan dan membentuk sikap, kepribadian, dan keterampilan peserta didik dalam mengamalkan ajaran agamanya, yang dilaksanakan sekurangkurangnya melalui mata pelajaran pada semua jalur, jenjang dan jenis pendidikan (Khairiyah \& Zen, 2017, hal. 19). Maka PAI ini menjadi salah satu mata pelajaran pendukung pembinaan karakter bagi sikap siswa. Dalam mengimplementasikan rangkaian penilaian sikap ini, menggunakan prosedur/tahapan penilaian yang sudah ditetapkan oleh Pemerintah. Berikut adalah pemaparannya:

\section{Pembahasan Penyusunan Instrumen Penilaian Domain Afektif oleh Guru PAI di SMP Negeri 2 Bandung dan SMP Salman Al-Farisi Bandung}

Dalam sebuah prosedur, perencanaan menjadi langkah awal dalam memulai tahapannya. Begitu pula dalam prosedur penilaian sikap, terdapat tahap perencanaan yang mesti dirancang untuk gambaran pelaksanaan penilaian sikap ke depannya. Merujuk pada UU Nomor 14 Tahun 2005 tentang Guru dan Dosen dan PP Nomor 19 Tahun 2005, seorang pendidik dikatakan memiliki keprofesionalan jika mereka setidaknya memiliki 4 kompetensi, salah satunya tentang kompetensi pedagogik. Dalam Standar Nasional Pendidikan, penjelasan Pasal 28 ayat (3) butir a dikemukakan, bahwa kompetensi pedagogik adalah kemampuan mengelola pembelajaran peserta didik yang meliputi pemahaman terhadap peserta didik, perancangan dan pelaksanaan pembelajaran, evaluasi hasil belajar, dan pengembangan peserta didik untuk mengaktualisasikan berbagai potensi yang dimilikinya. Contoh kompetensi pedagogik pada evaluasi hasil belajar yakni merancang dan melaksanakan evaluasi pembelajaran yang kompetensi tersebut terdiri dari merancang dan melaksanakan evaluasi (assesment) proses dan hasil belajar secara berkesinambungan dengan berbagai metode; menganalisis hasil evaluasi proses dan hasil belajar untuk menentukan tingkat ketuntasan belajar (mastery learning); dan memanfaatkan hasil penilaian pembelajaran untuk perbaikan program pembelajaran secara umum (Kunandar, 2008, hal. 76). Dari teori tersebut kita dapat cermati bahwa dalam melakukan evaluasi pembelajaran memerlukan perencanaan dalam pelaksanaannya.

Dalam merencanakan penilaian sikap, guru PAI di sekolah berpedoman pada panduan yang Pemerintah sediakan. Dengan panduan tersebut, maka penilaian sikap diharapkan menjadikan siswa berakhlak mulia. Berkarakter positif dalam semua lingkup kehidupan termasuk pada aspek spiritual dan aspek sosial. Bersandarkan pada panduan, maka dilakukan pengkajian peraturan, KI dan $\mathrm{KD}$, sehingga terbentuklah sebuah format penilaian sikap secara umum yang dibuat oleh Kurikulum Sekolah dan format penilaian sikap pada RPP yang dibuat guru sebagai bentuk pengembangan yang dilakukan. Di Salman, pedoman yang digunakan adalah juga pada sumber yang sama, namun terdapat pedoman lain yang merupakan pengembangan dari Kurikulum Khas Yayasan yakni Leadership dan Green Education. Tujuannya tidak lain supaya diketahui perkembangan sikap siswa agar hal positif bisa diaplikasikan dalam kehidupan sehari-hari (WGP.1A, WGP.1B, WGB.1, WWK.1, WKS.2, WKK.2, WGB.2, WWK.2).

Hal yang dilakukan di SMPN 2 Bandung ini sejalan dengan teori yang disampaikan, bahwa berdasarkan Permendikbud Nomor 24 Tahun 2016, mengenai kompetensi inti dan kompetensi dasar, diketahui bahwa $\mathrm{KD}$ dari KI.1 dan KI.2 hanya ada pada mata pelajaran PABP dan PPKn, sedangkan pada mata pelajaran lainnya tidak 
dikembangkan KD. Penilaian sikap pada mapel PABP dan PPKn akan diturunkan dari KD pada KI.1 dan KI.2, yang kemudian dirumuskan indikatornya. Indikator sikap ini diamati dan dicatat pada jurnal seperti pada mata pelajaran lainnya (Kementerian Pendidikan dan Kebudayaan, 2017, hal. 47-48). Terkait pengembangan kurikulum yang dilakukan di Salman, maka hal tersebut di luar pembahasan terkait perencanaan penilaian sikap, karena dalam pelaksanaan kurikulum khas yayasannya sendiri berpacu pula pada langkahlangkah yang diarahkan dari pedoman penilaian kurikulum 2013, sehingga tidak masalah. Kurikulum khas Salman hanya sebagai bentuk inovasi kurikulum yang Yayasan Salman Al-Farisi Bandung lakukan.

Ketika merencanakan instrumen penilaian sikap maka pengembangan disesuaikan dengan budaya sekolah. Dalam membuat sebuah instrumen penilaian sikap yang berkualitas, di SMPN 2 Bandung pembuatan kisi-kisi belum rutin dilakukan sehingga belum ditemukan standar analisis bagi penilaian sikap, masih cukup dengan judgement dari guru yang bersangkutan saja melalui upaya pengamatan pada umumnya. Di Salman pun demikian, dalam membuat sebuah instrumen penilaian sikap yang berkualitas, pembuatan kisi-kisi dilakukan berdasarkan indikator yang ada, masih cukup dengan judgement dari guru yang bersangkutan saja karena dirasa masih cukup objektif (WGP.1A, WGP.1B, WGP.1C, WWK.1, WWK.2, WGP.2).

Hal ini nyatanya menjadi masalah yang sama dengan penelitian lain yang menunjukkan bahwa guru PAI di SMP Islam Sultan Agung 4 Semarang pun tidak melaksanakan penilaian afektif sesuai dengan perencanaan, namun hanya menggunaan teknik pengamatan harian dan pembiasaan dapat dijadikan sebagai acuan untuk melakukan evaluasi afektif. Hal ini dikarenakan guru merasa telah hafal dengan karakteristik siswa sehingga guru sudah dapat memberikan pertimbangan tersendiri terhadap kompetensi afektif siswa. Selain itu, guru juga belum mendapatkan pembekalan yang spesifik terhadap evaluasi afektif siswa itu sendiri, sehingga tidak ada lembar pengamatan khusus untuk evaluasi afektif. Sedikitnya waktu yang tersedia untuk mengevaluasi menjadi kendala pelaksanaan evaluasi afektif tidak sesuai dengan perencanaan (Betwan, 2019, hal. 52).

Sebagaimana teori menjelaskan bahwa perencanaan penilaian hasil belajar oleh satuan pendidikan diuraikan sebagai berikut. 1. Menetapkan KKM; 2. Menyusun kisi-kisi penilaian mata pelajaran; 3. Menyusun instrumen penilaian dan pedoman penskorannya; 4 . Melakukan analisis kualitas instrumen; 5. Melakukan penilaian (pengujian); 6 . Mengolah, menganalisis, dan menginterpretasikan hasil penilaian; 7 . Melaporkan hasil penilaian; dan 8 . Memanfaatkan laporan hasil penilaian (Kementerian Pendidikan dan Kebudayaan, 2017, hal. 104). Maka bagi guru PAI di SMPN 2 Bandung belum secara menyeluruh melaksanakan apa yang tercantum dalam panduan, sedangkan guru PAI di SMP Salman AlFarisi Bandung sudah cukup melaksanakan apa yang dijelaskan dalam panduan. Namun terkait analisis kualitas instrumen penilaian sikap, kedua guru PAI dari kedua sekolah unggulan tersebut belum melaksanakannya, padahal dalam teori disebutkan, untuk menyusun indikator pencapaian kompetensi pada KD dari KI.1 dan KI.2 diperlukan analisis kompetensi dan analisis substansi bahan ajar. Dalam melakukan analisis kompetensi digunakan kata kerja operasional untuk aspek sikap. Analisis substansi bahan ajar dilakukan dengan menguraikan ruang lingkup materi sebagaimana dirumuskan 
dalam KD dari KI.1 dan KI.2 (Kementerian Pendidikan dan Kebudayaan, 2017, hal. 47-48).

Dalam perencanaannya, secara langsung ataupun tidak, akan ada saja pihak yang terlibat. Pihak yang dilibatkan dalam perencanaan penilaian sikap secara umum adalah semua pihak, namun secara khusus yakni Wakasek Kurikulum, Wakasek Kesiswaan, wali kelas, guru mata pelajaran (PAI dan PKN) dan guru BK. Di Salman pun serupa, namun secara khusus tidak hanya pihak-pihak yang disebutkan saja yang terlibat, namun ada guru Leadership yang memandu pula dalam pembinaan penilaian sikap, karena semua guru mata pelajaran bekerjasama dengannya terkait pengaplikasian aspek Leadership pada mata pelajaran, maka semua guru mata pelajaran pun secara khusus juga terlibat di dalamnya. Hal ini sejalan dengan teori yang ada, bahwa mengenai perencanaan, di dalam jurnal penilaian, tidak hanya didasarkan pada apa yang dilihat langsung oleh pendidik, wali kelas, dan guru $\mathrm{BK}$, tetapi juga informasi lain yang relevan dan valid yang diterima dari berbagai sumber (Kementerian Pendidikan dan Kebudayaan, 2017, hal. 35).

Dalam teori tersebut dijelaskan, bahwa pendidik/guru, wali kelas dan guru BK terlibat di dalam pelaksanaan penilaian sikap, otomatis dalam merencanakannya pun mereka terlibat. Begitu pula manajemen sekolah di antaranya Wakasek Kurikulum dan Wakasek Kesiswaan. Dalam teorinya, terkait pihak sekolah dipisahkan bentuk tanggungjawabnya dalam melaksanakan penilaian sikap. Seperti yang dijelaskan dalam teori, bahwa penilaian hasil belajar oleh satuan pendidikan meliputi pengertian, lingkup, bentuk penilaian, instrumen, kriteria kenaikan kelas, kriteria kelulusan, perencanaan, pelaksanaan, pengolahan, pemanfaatan, dan tindak lanjut hasil penilaian
(Kementerian Pendidikan dan Kebudayaan, 2017, hal. 3).

Selama proses perencanaan penilaian sikap berlangsung, wajar akan selalu ada kendala. Secara umum, kendala yang dihadapi terdiri atas beberapa hal yakni pengendalian waktu, kemampuan guru yang kadang masih subjektif dalam melakukan penilaian sikap, dan di Salman ditambah dengan komunikasi (WGP.1A, WWK.1, WGP.2, WWK.2, WGB.2). Jika mengacu pada teori, menurut Stiggins (1994) seharusnya jika guru telah melek penilaian, maka ia akan memberikan dampak positif, di antaranya dapat mengatasi kelemahan tes standar yang kurang komprehensif mengevaluasi target prestasi, mampu menilai secara berkelanjutan, efisiensi waktu dan biaya, mampu meningkatkan keberdayaan guru dan siswa, siswa memahami kriteria penilaian yang akan ditujukan pada dirinya dan secara aktif terlibat menilai dirinya sendiri dan siswa lain, serta hasil penilaian dapat ditindaklanjuti dengan segera (Suastra \& Ristiati, 2016, hal. 306). Maka mengefesiensikan waktu dalam penilaian harus sudah menjadi suatu tanggung jawab yang guru upayakan.

Dapat disimpulkan bahwa penyusunan instrumen penilaian domain afektif oleh guru PAI di SMP Negeri 2 Bandung dan SMP Salman Al-Farisi Bandung sudah selaras dengan teori-teori perencanaan, namun ada beberapa hal yang belum selaras dengan teori-teori tersebut. Temuan yang selaras dengan teori-teori tersebut seperti pedoman yang digunakan dalam perencanaan penilaian sikap sudah sesuai dengan teori yakni berpacu pada panduan penilaian kurikulum 2013, meskipun di Salman ada sedikit perbedaan dengan dilakukannya inovasi pengembangan kurikulum sehingga berpengaruh pula pada bentuk penilaian yang dilakukan. Kemudian terkait pihak yang dilibatkan, secara umum sudah sesuai dengan teori, karena 
pada hakikatnya peran dan tanggung jawab masing-masing tenaga pendidik dan kependidikan sudah diatur di dalam peraturan perundang-undangan yang berlaku. Perkara yang harus digaris bawahi adalah ketika melakukan perencanaan penilaian sikap, hendaknya guru melakukan analisis kualitas terhadap instrumen penilaian yang dirancang, jangan hanya berpedoman pada judgement guru yang bersangkutan saja karena dalam aturan sudah dijelaskan, namun hal tersebut belum terjadi di SMP Negeri 2 Bandung dan SMP Salman Al-Farisi Bandung. Selain itu, dalam perancangan kisi-kisi instrumen penilaian sikap belum seluruhnya maksimal dilakukan oleh setiap guru, sehingga perlu upaya lebih lanjut. Dan terakhir, terkait kendala yang dihadapi dalam perencanaan penilaian sikap, hal yang sudah menjadi rahasia umum masih menjadi sebuah hambatan yakni terkait pengendalian waktu dan penilaian sikap yang kadang masih subjektif. Hal tersebut belum selaras dengan teori-teori profesionalisme guru dan panduan penilaian sikap.

\section{Pembahasan Pelaksanaan Penilaian Domain Afektif oleh Guru PAI di SMP Negeri 2 Bandung dan SMP Salman Al-Farisi Bandung}

Dalam melaksanakan pelaksana-an penilaian sikap, ada beberapa langkah yang perlu dilalui. Pertama, yakni proses pengamatan dalam pelaksanaan penilaian sikap. Pengamatan perilaku peserta didik, dilakukan baik saat siswa di dalam maupun di luar kelas selama berada di sekolah. Secara langsung dilakukan melalui pengamatan tanpa sepengetahuan siswa dan secara tidak langsung dilakukan melalui jurnal teknis/format penilaian sikap yang dipegang oleh guru. Hal yang diamati adalah sikap yang terlihat menonjol baik positif maupun negatif. Jika ditemukan siswa yang melanggar peraturan, maka dibantu oleh
Kesiswaan dan guru BK akan mendapatkan pengurangan poin dan pembinaan lebih lanjut. Di Salman, hal serupa demikian terjadi, namun pemantauan penilaian sikap dibantu juga dengan menggunakan buku penghubung yang bekerjasama dengan orang tua siswa sehingga pelaksanaan penilaian sikap secara tidak langsung juga dilakukan ketika siswa berada di rumah (WGP.1A, WGP.1B, WGP.1C, WWK.1, WKS.1, WGB.1, WSS.1A, WSS.1B, WSS.1C, WGP.2, WWK.2, WKS.2, WGB.2, WSS.2A, WSS.2B, WSS.2C)

Hal ini sejalan dengan teori yang digunakan, bahwa penilaian sikap dilakukan oleh guru mata pelajaran (selama proses pembelajaran pada jam pelajaran) dan/atau di luar jam pembelajaran, guru bimbingan konseling (BK), dan wali kelas (selama peserta didik di luar jam pelajaran) (Kementerian Pendidikan dan Kebudayaan, 2017, hal. 53). Maka penambahan pemantauan yang dilakukan di Salman adalah sebagai bentuk dari pengembangan pembiasaan sikap supaya dapat diaplikasikan dalam kehidupan sehari-hari dan hal ini patut diapresiasi.

Tahap kedua dalam pelaksanaan penilaian sikap yakni pencatatan. Pencatatan perilaku peserta didik, dilakukan dengan menggunakan instrumen penilaian sikap. Bentuknya berupa penggabungan dari format yang tercantum dalam buku guru dan pengembangan redaksi instrumen dari yang tercantum dalam RPP yang dibuat oleh guru. Untuk pencatatan tahap awal biasanya menggunakan catatan sementara dahulu melalui daftar nilai siswa. Hal yang dicatat adalah tingkah laku menonjol siswa baik secara positif maupun negatif dengan menggunakan simbol/tanda. Jika ditemukan pelanggaran, maka akan ada ketentuan poin yang berlaku bagi siswa yang bersangkutan. Ketentuan poin ini dibuat oleh Kesiswaan, pengurus OSIS dan 
Perwakilan Kelas dalam rangka menegakkan tata tertib sekolah. Di Salman hal serupa demikian dilakukan, apabila di kelas disesuaikan dengan materi pembelajaran dan apabila di luar kelas disesuaikan dengan kontrak belajar dengan siswa (WGP.1A, WGP.1B, WGP.1C, WWK.1, WKS.1, WGB.1, WSS.1A, WSS.1B, WSS.1C, WGP.2, WWK.2, WKS.2, WGB.2, WSS.2A, WSS.2B, WSS.2C).

Hal ini sejalan dengan teori yang digunakan, bahwa wali kelas, guru mata pelajaran, dan guru BK mencatat (perkembangan) sikap peserta didik segera setelah mereka menyaksikan dan/atau memperoleh informasi terpercaya mengenai perilaku peserta didik sangat baik/ kurang baik yang ditunjukkan peserta didik secara alami Kementerian Pendidikan dan Kebudayaan, 2017, hal. 37). Dan di dalam jurnal biasanya digunakan untuk mencatat perilaku peserta didik yang "ekstrem." Jurnal tidak hanya didasarkan pada apa yang dilihat langsung oleh pendidik, wali kelas, dan guru BK, tetapi juga informasi lain yang relevan dan valid yang diterima dari berbagai sumber (Kementerian Pendidikan dan Kebudayaan, 2017, hal. 35). Maka pencatatan terhadap hal-hal yang menonjol memang perlu dilakukan.

Kemudian, tahap ketiga yakni tahap penindaklanjutan. Penindaklanjutan hasil pengamatan di SMPN 2 Bandung dan di SMP Salman Al-Farisi Bandung, terbagi ke dalam tiga cara. Bagi siswa yang terbaik sikapnya, akan diberi reward untuk menjadi tutor sebaya atau leader group membimbing temannya yang lain, lalu diberikan nilai unggul/tambahan dan apresiasi. Kemudian bagi siswa yang sikapnya baik secara umum, interpretasinya cukup disimpulkan saja, ia termasuk kategori aman dan belum ada tindak lanjut lebih untuk saat ini. Sedangkan bagi siswa yang sikapnya kurang baik maka akan ada punishment berupa peneguran, akan mendapatkan perhatian khusus dengan dilakukannya analisis terlebih dahulu, kemudian diberikan treatment berupa nesehat melalui pembinaan, dan apabila sudah terlanjur tidak wajar akan dipanggil orang tuanya. Prosesnya dibantu oleh wali kelas, kesiswaan dan guru BK (WGP.1A, WGP.1B, WGP.1C, WWK.1, WKS.1, WGB.1, WSS.1A, WSS.1B, WSS.1C, WGP.2, WWK.2, WKS.2, WGB.2, WSS.2A, WSS.2B, WSS.2C).

Hal ini sejalan dengan teori yang ada, bahwa peserta didik yang dicatat dalam jurnal pada dasarnya adalah mereka yang menunjukkan perilaku yang sangat baik atau kurang baik secara alami (peserta didik yang menunjukkan sikap baik tidak harus dicatat dalam jurnal) Kementerian Pendidikan dan Kebudayaan, 2017, hal. 36). Hal tersebut dilakukan karena apabila melakukan penindaklanjutan secara rinci kepada semua siswa yang beragam karakternya, maka hal tersebut belum bisa maksimal dilakukan.

Tahap keempat, yakni pendeskripsian. Pendeskripsian perilaku peserta didik di SMPN 2 Bandung dan di SMP Salman Al-Farisi Bandung, pengolahan resminya dilakukan oleh Kurikulum. Redaksi pendeskripsian dari hasil pengamatan dilakukan dengan standar yang sama untuk semua mata pelajaran, berupa gambaran secara umum, angka dari persentase, kata-kata dan umumnya deksripsi (WGP.1A, WGP.1B, WGP.1C, WWK.1, WKS.1, WGB.1, WSS.1A, WSS.1B, WSS.1C, WGP.2, WWK.2, WKS.2, WGB.2, WSS.2A, WSS.2B, WSS.2C). Dengan menggunakan pemilihan kata yang bijaksana, yang sebelumnya dilakukan pendeskripsian penilaian menggunakan angka atau huruf terlebih dahulu sebagai catatan sementara untuk kasus yang menonjol baik positif maupun negatif. Hal ini sejalan dengan teori yang ada, 
bahwa pelaporan hasil penilaian sikap harus dalam bentuk predikat dan deskripsi (Kementerian Pendidikan dan Kebudayaan, 2017, hal. 54).

Setelah keempat tahap tersebut dilalui, pastinya dalam prosesnya melibatkan berbagai pihak. Pihak yang dilibatkan selama proses pelaksanaan penilaian sikap, secara umum semua pihak dalam lingkungan pendidikan terlibat namun ketika di kelas hanya guru dan siswa yang bersangkutan saja. Secara khusus yang terlibat adalah guru mata pelajaran (PAI dan PKN), siswa, wali kelas, guru BK, Wakasek Kesiswaan, pengurus OSIS, serta Wakasek Sarana dan Prasarana dan Perwakilan Kelas sebagai tambahannya untuk di SMPN 2 Bandung.

Hal ini sejalan dengan teori yang ditemukan bahwa penilaian sikap dilakukan oleh guru mata pelajaran (selama proses pembelajaran pada jam pelajaran) dan/atau di luar jam pembelajaran, guru bimbingan konseling (BK), dan wali kelas (selama peserta didik di luar jam pelajaran) (Kementerian Pendidikan dan Kebudayaan, 2017, hal. 53). Dijelaskan beberapa hal yang perlu diperhatikan dalam melaksanakan penilaian (mengikuti perkembangan) sikap dengan teknik observasi: 1 . Jurnal penilaian (perkembangan) sikap ditulis oleh wali kelas, guru mata pelajaran, dan guru BK selama periode satu semester; 2. Bagi wali kelas, 1 (satu) jurnal digunakan untuk satu kelas yang menjadi tanggungjawabnya; 3. Bagi guru mata pelajaran, 1 (satu) jurnal digunakan untuk setiap kelas yang diajarnya; 4. Bagi guru $\mathrm{BK}, 1$ (satu) jurnal digunakan untuk setiap kelas di bawah bimbingannya, dan seterusnya (Kementerian Pendidikan dan Kebudayaan, 2017, hal. 36). Maka semua pihak yang terlibat adalah saling berkaitan satu sama lain.

Dalam melaksanakan proses pelaksanaan penilaian sikap wajar ada kendala. Kendala yang dihadapi selama proses pelaksanaan penilaian sikap ini terdiri atas beberapa hal. Di antara kedua sekolah unggulan tersebut, di antaranya yaitu fasilitas yang kurang memadai, waktu dan sumber daya manusia yang perlu diefektifkan lagi, fluktuatifnya perkembangan sikap siswa apalagi ketika siswa sudah di luar sekolah tidak lagi dalam jangkauan pemantauan sekolah, dan masih kompleksnya pelaksanaan teknis dalam penilaian sikap sehingga kadang memunculkan subjektifitas dalam memutuskannya (WGP.1A, WGP.1B, WWK.1，WKS.1，WGB.1，WGP.2, WWK.2, WKS.2, WGB.2).

Jika mengacu pada teori, pelaksanaan penilaian adalah eksekusi atas perencanaan penilaian. Waktu dan frekuensi pelaksanaan penilaian dilakukan berdasarkan pemetaan dan perencanaan yang dilakukan oleh pendidik. Panduan Penilaian oleh Pendidik dan Satuan Pendidikan SMP sebagaimana yang tercantum dalam program semester dan program tahunan (Kementerian Pendidikan dan Kebudayaan, 2017, hal. 70-71). Maka dalam hal waktu, untuk efektifitas sebenarnya perlu direncanakan pemetaannya lebih matang sejak awal. Terkait penilaian yang masih subjektif, seharusnya apabila mengacu pada teori, sesuai yang dikemukakan oleh Stigins (1994) yang menyatakan bahwa agar penilaian dapat berlangsung dengan kualitas baik, maka guru perlu dituntun dengan prinsip-prinsip dasar penilaian. Prinsip-prinsip penilaian tersebut meliputi: objektif, terpadu, ekonomis, transparan, akuntabel, dan edukatif (Kunandar, 2013, hal. 5; (Suastra \& Ristiati, 2016, hal. 312). Dalam penilaian yang objektif, tidak boleh dipengaruhi oleh subjektivitas penilai. Karena itu perlu dirumuskan pedoman penilaian (rubrik) sehingga dapat menyamakan persepsi penilai dan meminimalisir subjektivitas, apalagi dalam penilaian 
kinerja yang cakupan, otentisitas, dan kriteria penilaiannya sangat kompleks. Untuk penilai lebih dari satu perlu dilihat reliabilitas atau konsistensi antar penilai (inter-rater reliability) untuk menjamin objektivitas setiap penilai (Kementerian Pendidikan dan Kebudayaan, 2017, hal. 12).

Dapat disimpulkan bahwa pelaksanaan penilaian domain afektif oleh guru PAI di SMP Negeri 2 Bandung dan SMP Salman Al-Farisi Bandung sudah selaras dengan teori-teori pelaksanaan, namun ada beberapa hal yang belum selaras dengan teori-teori tersebut. Temuan yang selaras dengan teori-teori tersebut seperti tentang beragam tahapan yang dilewati dalam melaksanakan perencanaan penilaian sikap, yaitu tahap pengamatan, pencatatan, penindaklanjutan dan tahap pendeskripsian. Ke semua tahapan tersebut, sudah terjalankan sesuai dengan teori yang seharusnya. Tak lupa terkait pihak yang dilibatkannya pun adalah orang-orang yang sudah sewajarnya berperan ketika melaksanakan penilaian sikap di lapangan, sehingga dalam pelaksanaannya sesuai dengan teori yang berlaku. Perkara yang harus digaris bawahi adalah ketika terdapat kendala dalam pelaksanaan penilaian sikap, hal yang sudah menjadi rahasia umum masih menjadi sebuah hambatan yakni terkait pengendalian waktu dan penilaian sikap yang terkadang masih subjektif. Hal tersebut belum selaras dengan teori-teori profesionalisme guru dan panduan penilaian sikap.

Pembahasan Hasil Proses Penilaian Domain Afektif oleh Guru PAI di SMP Negeri 2 Bandung dan SMP Salman Al-Farisi Bandung

Tahap pengolahan data penilaian sikap (laporan diri) di SMPN 2 Bandung, dimulai dari pengolahan data dari hasil angket penilaian diri atau antar teman yang terdiri dari 59 pernyataan aspek spiritual dan sosial yang dibuat oleh kurikulum. Nilai sikap yang ditampilkan di dalam rapot siswa adalah sikap siswa yang menonjol/terlihat secara umum. Selain itu, dilakukan pula pengolahan nilai sikap dari hasil rekapan keseharian siswa di kelasnya sesuai dengan materi yang dipelajari. Pengolahan akan terproses dengan cepat bagi yang nilai akhir sikapnya baik, berbeda dengan siswa yang nilai akhir sikapnya kurang baik, perlu ada penanganan serius yang bekerjasama dengan guru BK. Akhirnya nilai tersebut dikalkulasikan dengan nilai dari aspek yang lain lalu dihimpun oleh wali kelas, kemudian diserahkan pada kurikulum untuk diolah melalui aplikasi (WKK.1).

Sedangkan di Salman, pengolahan data penilaian sikap (laporan diri), dimulai dari aturan pengolahan penilaian sikap dari aspek spiritual yang diserahkan pada guru PAI dan aspek sosial yang diserahkan kepada guru PKN yang pembagian persentasenya fifty-fifty. Karena di Salman terdapat kurikulum khas yayasan maka pengolahan penilaian penekanannya ada pada mata pelajaran Leadership ini. Ketujuh aspek dalam Leadership diaplikasikan ke setiap mata pelajaran. Akhirnya, akan membentuk pengolahan hasil akhir penilaian sikap dengan pembagian $40 \%$ nilai dari guru Leadership, 40\% nilai dari wali kelas, 20\% nilai dari guru mata pelajaran. Maka secara umum, rapot yang dipakai di Salman terdiri atas 4 jenis, yakni rapot umum dari Dinas Pendidikan yang berisi nilai mata pelajaran secara umum, rapot Leadership, rapot GE (Green Education), dan rapot Diniyyah (mata pelajaran khusus praktek keagamaan di luar mata pelajaran PAI, seperti tahfidz, do'a, hadits, shalat, wudhu dan sebagainya).

Alurnya yakni nilai sikap dari guru mata pelajaran yang sudah diolah diserahkan kepada guru Leadership, lalu diberikan kepada Kurikulum, dilakukan pengecekan kepada wali kelas, kemudian 
diserahkan kembali kepada Kurikulum untuk diolah menjadi nilai dalam rapot siswa. Ke semua proses tersebut, dibantu melalui sebuah sistem yang hanya sebagian sekolah memilikinya, yakni aplikasi SIRAWA. Nilai tersebut nanti digabungkan dengan nilai aspek lainnya di dalam aplikasi ini. Outputnya, dalam rapot akan ditampilkan keseluruhan penilaian secara detail, selain tercantum nilai akhir setiap mata pelajaran juga tercantum nilai setiap bab/ KD dari mata pelajaran yang dipelajari (WKK.2).

Hal ini sejalan dengan teori yang ada, bahwa langkah-langkah dalam pengolahan hasil penilaian sikap untuk membuat deskripsi nilai/perkembangan sikap selama satu semester itu meliputi: (Kementerian Pendidikan dan Kebudayaan, 2017, hal. 54).

a. Guru mata pelajaran, wali kelas dan guru BK masing-masing mengelompokkan (menandai) catatan-catatan sikap pada jurnal yang dibuatnya ke dalam sikap spiritual dan sikap sosial (apabila pada jurnal belum ada kolom butir nilai).

b. Guru mata pelajaran, wali kelas dan guru $\mathrm{BK}$ masing-masing membuat rumusan deskripsi singkat sikap spiritual dan sikap sosial berdasarkan catatan-catatan jurnal untuk setiap peserta didik.

c. Wali kelas mengumpulkan deskripsi singkat sikap dari guru mata pelajaran dan guru BK. Dengan memperhatikan deskripsi singkat sikap spiritual dan sosial dari guru mata pelajaran, guru BK, dan wali kelas yang bersangkutan, wali kelas menyimpulkan (merumuskan deskripsi) capaian sikap spiritual dan sosial setiap peserta didik.

d. Pelaporan hasil penilaian sikap dalam bentuk predikat dan deskripsi.

Secara umum, keempat poin ini sudah tercantum dalam rangkaian bentuk pengolahan yang dilakukan baik di SMP Negeri 2 Bandung maupun di SMP Salman Al-Farisi Bandung. Meskipun dari masing-masing sekolah mempunyai perbedaan dengan mengaplikasikan bentuk penilaian yang disesuaikan dengan program sekolah masing-masing. Namun panduan secara umum, secara nyata adalah dasar yang dipakai oleh setiap sekolah sehingga teori dan pelaksanaan sudah selaras. Secara khusus, terkait rambu-rambu rumusan predikat dan deskripsi perkembangan sikap dalam panduan, juga sudah diaplikasikan oleh kedua sekolah unggulan tersebut.

Tahap selanjutnya yakni tindak lanjut. Tindak lanjut dari pengolahan hasil penilaian sikap berupa apa bentuk pemanfaatan yang akan dilakukan dari hasil pengolahan laporan penilaian sikap yang sudah dibuat. Di SMPN 2 Bandung digunakan sebagai acuan untuk mengamati perkembangan sikap siswa, ketika masih ada yang kurang menjadi informasi untuk diperbaiki melalui kerjasama dengan pihak terkait. Di Salman, hsl ini digunakan sebagai pembelajaran supaya lebih berhati-hati lagi dalam bersikap. Lalu bisa menjadi kajian khusus untuk perbaikan sistem pembelajaran ke depannya, dan terakhir dapat dijadikan sebagai arsip untuk patokan sidang kenaikan kelas, pemetaan kelas, dan bisa menjadi catatan siswa pada tingkat kelas berikutnya dan menjadi acuan kelulusan siswa (WGP.1A, WGP.1B, WGP.1C, WGB.1, WKK.1, WWK.1, WGP.2, WGB.2, WWK.2, WKK.2).

Hal ini sejalan dengan teori yang digunakan, bahwa dalam Peraturan Menteri Pendidikan Nasional No 16 Tahun 2007 dijelaskan pula kompetensi inti guru dalam memanfaatkan hasil penilaian dan evaluasi untuk kepentingan pembelajaran yang terdiri dari, menggunakan informasi hasil penilaian dan evaluasi untuk menentukan 
ketuntasan belajar; menggunakan informasi hasil penilaian dan evaluasi untuk merancang program remedial dan pengayaan; mengkomunikasikan hasil penilaian dan evaluasi kepada pemangku kepentingan; dan memanfaatkan informasi hasil penilaian dan evaluasi pembelajaran untuk meningkatkan kualitas pembelajaran (Peraturan Menteri Pendidikan Nasional Nomor 16 Tahun 2007). Maka, memanfaatkan informasi hasil penilaian dilakukan melalui upaya tindak lanjut ini. Perilaku sikap spiritual dan sosial yang teramati dan tercatat dalam jurnal hendaknya guru, wali kelas maupun guru BK harus menjadi dasar untuk tindak lanjut oleh pihak sekolah. Bila perilaku sikap yang kurang termasuk dalam sikap spiritual maupun sikap sosial, tindak lanjut berupa pembinaan terhadap peserta didik dapat dilakukan oleh semua pendidik di sekolah Kementerian Pendidikan dan Kebudayaan, 2017, hal. 57).

Dalam proses pengolahan hasil penilaian pastinya akan ada saja pihak yang dilibatkan. Pihak yang dilibatkan dalam mengolah hasil proses penilaian sikap, di antaranya guru mata pelajaran (di Salman tambahannya ada guru khusus, yakni guru Leadership), wali kelas, guru BK, dan Wakasek Kurikulum. Hal ini sejalan dengan teori yang digunakan, bahwa dalam proses pengolahan hasil penilaian, guru mata pelajaran, wali kelas dan guru BK masing-masing mengelompokkan (menandai) catatancatatan sikap pada jurnal yang dibuatnya ke dalam sikap spiritual dan sikap sosial (apabila pada jurnal belum ada kolom butir nilai). (Kementerian Pendidikan dan Kebudayaan, 2017, hal. 54). Terkhusus guru Leadership ini kaitannya adalah dengan output dari inovasi pengembangan kurikulum yang dilakukan di Salman, dan tidak masalah. Ini artinya, mereka semua terlibat dalam proses pengolahan hasil penilaian sikap siswa.
Sebagaimana dalam setiap
prosedur terjadi, dalam tahap pengolahan hasil penilaian sikap pun wajar ada kendala. Kendala yang dihadapi selama mengolah hasil dari proses pelaksanaan penilaian sikap ini, di antaranya bagaimana mengatur waktu yang lebih efektif lagi, karena proses pengolahan nilai membutuhkan waktu yang maksimal namun tetap efisien, akibatnya kadang seperti di Salman, hal ini menyebabkan timbulnya keterlambatan dalam penyerahan nilai akibat kebiasaan penundaan sehingga menghambat proses pengolahan nilai. Kemudian tuntutan guru (khususnya PAI) yang begitu besar, karena segala perilaku siswa baik dan buruknya di sekolah akan kembali pada tanggung jawab guru terkait dalam melakukan pembinaan sikap, maka perlu kehatihatian dalam pelaporan yang belum maksimal ini sehingga dapat meminimalisir keraguan dalam objektifitas penilaian. Terkait kendala ini, acuannya sama seperti teori yang dijelaskan sebelumnya, bahwa kendala seperti pengaturan waktu dan objektifitas dalam penilaian adalah hal yang sudah semestinya menjadi upaya yang diusahakan untuk diminimalisir (WGP.1A, WGP.1B, WWK.1, WKK.2, WGB.1, WGP.2, WWK.2, WKK.2, WGB.2).

Terkait tuntutan guru yang begitu besar, sejalan dengan teori yang digunakan bahwa memahami tuntutan sudah menjadi hal yang harus disadari ketika mengaplikasikan profesionalisme guru. Kesadaran akan tuntutan ini tercantum dalam cara dalam melaksanakan profesionalisme guru, yakni sebagai berikut. Pertama; dengan memahami tuntutan standar profesi yang ada. Kedua; mencapai kualifikasi dan kompetensi yang dipersyaratkan. Ketiga; membangun hubungan kesejawatan yang baik dan luas termasuk lewat organisasi profesi. Keempat; mengembangkan etos 
kerja atau budaya kerja yang mengutamakan pelayanan bermutu tinggi kepada konstituen. Kelima; mengadopsi inovasi atau mengembangkan kreativitas dalam pemanfaatan teknologi komunikasi dan informasi mutakhir agar senantiasa tidak ketinggalan dalam kemampuannya mengelola pelajaran (Yusutria, 2017, hal. 42) (Muhson, 2004, hal. 97).

Memahami tanggung jawab guru untuk menerima apapun tuntutan yang ada sejalan pula dengan kewajiban guru dalam melaksanakan kompetensinya. Dalam Undang-Undang No 14 tahun 2005 tentang Guru dan Dosen Bab I Pasal 1 ayat (10) dinyatakan bahwa kompetensi adalah seperangkat pengetahuan, keterampilan, dan perilaku yang harus dimiliki, dihayati, dan dikuasai oleh guru atau dosen dalam melaksanakan tugas keprofesionalannya, sehingga kompetensi yang dimiliki seorang guru menunjukkan profesionalisme guru tersebut (UndangUndang RI Nomor 14 Tahun 2005). Kompetensi yang harus dimiliki seorang guru yang mencakup empat aspek tersebut, di antaranya kompetensi kepribadian dan kompetensi sosial.

Dalam Standar Nasional Pendidikan, penjelasan Pasal 28 ayat (3) butir b, dikemukakan bahwa yang dimaksud dengan kompetensi kepribadian adalah kemampuan kepribadian yang mantap, stabil, dewasa, arif, dan berwibawa, menjadi teladan bagi peserta didik, dan berakhlak mulia (E, 2008, hal. 75), sehingga sudah sepatutnya guru berusaha untuk membimbing peserta didiknya supaya berakhlak mulia. Tak lupa dalam Standar Nasional Pendidikan, penjelasan Pasal 28 ayat (3) butir d dikemukakan pula bahwa yang dimaksud dengan kompetensi sosial adalah kemampuan guru sebagai bagian dari masyarakat untuk berkomunikasi dan bergaul secara efektif dengan peserta didik, sesama pendidik, tenaga kependidikan, orang tua/wali peserta didik, dan masyarakat sekitar (E, 2008, hal. 75). Sehingga untuk mewujudkan pembinaan akhlakul karimah bagi siswa supaya tidak hanya menjadi tanggung jawab satu pihak, maka guru perlu mengasah keterampilan berkomuni-kasinya melalui ajakan kerjasama dengan orang tua siswa dan pihak lainnya yang terkait.

Dapat disimpulkan bahwa hasil proses penilaian domain afektif oleh Guru PAI di SMP Negeri 2 Bandung dan SMP Salman Al-Farisi Bandung sudah selaras dengan teori-teori pengolahan hasil penilaian sikap, namun ada beberapa hal yang belum selaras dengan teori-teori tersebut. Temuan yang selaras dengan teori-teori tersebut seperti terkait teknik pengolahan hasil penilaian sikap yang sudah sesuai dengan panduan pengolahan penilaian secara umum, meskipun masing-masing sekolah mempunyai turunan teknis dengan caranya masing-masing. Kemudian terkait bentuk pemanfaatan hasil pengolahan penilaian sikap sebagai upaya dari tindak lanjut dan pihak-pihak yang dilibatkannya sesuai pula dengan teori yang ada. Perkara yang harus digaris bawahi adalah ketika terdapat kendala dalam pengolahan hasil penilaian sikap, hal yang sudah menjadi rahasia umum masih menjadi sebuah hambatan yakni terkait pengaturan waktu dan penilaian sikap yang terkadang masih subjektif. Serta terkait tuntutan guru yang terasa begitu besar dalam mempertanggungjawabkan hasil penilaian sikap setiap peserta didiknya. Hal tersebut dikarenakan belum saling mendukungnya peran semua pihak termasuk orang tua, sehingga perlu diupayakan. Hal tersebut belum selaras dengan teoriteori profesionalisme guru dan panduan penilaian sikap.

Tantangan dan hambatan dalam evaluasi ranah afektif di SMP Islam Sultan Agung 4 Semarang adalah: (1) Waktu; Berbeda dengan evaluasi kognitif 
yang kerap dilakukan kapan dan dimanapun setelah memberi materi pelajaran kepada siswa untuk mengetahui tingkat pemahaman dan penguasaan siswa terhadap materi pelajaran. Evaluasi afektif tidak dapat dilakukan dengan serta merta setelah penyampaian pokok materi pelajaran dan dapat dilakukan dalam jangka waktu yang relatif pendek. Evaluasi ranah afektif harus dilakukan dalam jangka waktu yang relatif lama, karena yang dievaluasi adalah masalah sikap dan nilai, dan evaluasi tidak hanya dilakukan di kelas, namun juga harus dilakukan di luar sekolah. Hal tersebut juga diakui oleh guru SMP Islam Sultan Agung 4 Semarang bahwa evaluasi ranah afektif membutuhkan waktu yang cukup panjang. Evaluasi sikap ini tidak dapat dilakukan sesaat, karena yang dinilai terkait dengan sikap, yang sewaktu-waktu dapat berubah. (2) Penyusunan instrumen; Kendala yang dihadapi oleh guru adalah penyusunan instrumen penilaian ranah afektif. Berbeda dengan penyusunan instrumen penilaian ranah kognitif, penyusunan instrumen ranah afektif lebih sulit, meskipun secara teoritik banyak para pakar dan ahli pendidikan telah merumuskan beberapa skala pengukuran sikap, namun pengukuran tersebut hanya berlaku untuk pengukuran sikap secara umum. (Betwan, 2019, hal. 57)

\section{KESIMPULAN}

Berdasarkan hasil temuan dan pembahasan mengenai Studi Realitas Prosedur Penilaian Domain Afektif oleh Guru PAI di SMP Negeri 2 Bandung dan SMP Salman Al-Farisi Bandung, dapat terlihat bahwa tahapan perencanaan, pelaksanaan, dan pengolahan hasil penilaian sikap secara umum sudah selaras dan berjalan dengan baik sesuai dengan teorinya sehingga sudah hampir melaksanakan tujuan pendidikan seutuhnya. Namun ada beberapa hal yang belum selaras dengan panduan, di antaranya terkait perencanaan penilaian sikap yang belum maksimal karena guru masih menganalisis kualitas instrumen penilaian sikap melalui upaya judgement guru yang bersangkutan saja, belum ada upaya penganalisisan secara khusus. Selain itu, dalam perancangan kisi-kisi instrumen penilaian sikap belum seluruhnya maksimal dilakukan oleh setiap guru, sehingga perlu upaya lebih lanjut. Kemudian, dalam hal pengolahan hasil penilaian sikap masih ada saja kendala yang sudah menjadi rahasia umum yakni terkait pengaturan waktu dan penilaian sikap yang kadang masih subjektif, karena memang pada kenyataannya di lapangan, hal tersebut tak mudah seperti yang dibayangkan. Maka tugas terdekat adalah bagaimana hal yang belum selaras tersebut bisa diupayakan untuk diminimalisir secara berkala, supaya tujuan pendidikan nasional segera bisa teraplikasikan secara utuh, yakni salah satunya membentuk peserta didik yang berakhlak mulia.

Implikasi dari penelitian ini menunjukkan bahwa dengan adanya tahapan perencanaan, pelaksanaan dan pengolahan hasil penilaian sikap yang sesuai dengan panduan menjadi penting dilakukan, karena apabila sudah dilaksanakan sesuai dengan prosedur dapat mewujudkan tujuan dari penilaian sikap yang diharapkan yakni terbentuknya peserta didik yang berakhlak mulia.

Rekomendasi yang ditawarkan dari hasil penelitian ini adalah bagi guru, supaya berperan aktif dalam kegiatan pelatihan-pelatihan, terkait keteladanan dan keterampilan melakukan penilaian, khususnya aspek sikap supaya dapat memaksimalkan peran dalam merencanakan kisi-kisi dan menganalisis kualitas instrumen penilaian sikap. Bagi sekolah yang bersangkutan, menjadi referensi untuk semakin memperkuat kerja sama antar pihak terkait dalam 
Studi Prosedur Penilaian Domain Afektif oleh Guru Pai di SMP Negeri 2 Bandung dan SMP Salman Al-Farisi Bandung

melaksanakan pembinaan sikap terbaik, antar tenaga pendidik, tenaga pendidikan maupun orang tua siswa. Bagi prodi IPAI, menjadi masukan dalam pengembangan konten materi mata kuliah evaluasi pembelajaran, supaya memaksimalkan upaya dalam pembinaan keterampilan prosedur penilaian sikap ketika nanti PPL di sekolah. Dan terakhir, bagi penelitian selanjutnya, hendaknya penelitian ini dilanjutkan pada jenjang SMA/sederajat supaya lebih luas dan lengkap.

\section{REFERENSI}

Anwar, K. (2015). Jaminan Mutu dan Upaya Pengembangan Profesionalitas Guru Pada Abad Pengetahuan. Nur El-Islam, 105.

Anwar, S., \& Fakhruddin, A. (2016). Pelaksanaan Standar Penilaian oleh Guru Pendidikan Agama Islam di Sekolah. Ta'lim, 14(2), 139-155.

Arifin, Z. (2017). Evaluasi Pembelajaran. Bandung: PT. Remaja Rosdakarya.

Aulia, M. (2018). Pelaksanaan Penilaian Sikap Spritual dan Sikap Sosial pada Mata Pelajaran Pendidikan Agama Islam dan Budi Pekerti di SMPN 5 Batusangkar. Skripsi Sarjana Pendidikan Agama Islam. Institut Agama Islam Negeri Batusangkar.

Betwan. (2019, Februari). Pentingnya Evaluasi Afektif pada Pembelajaran PAI di Sekolah. Al-Fikri, 2(1), 45-60.
Kementerian Pendidikan dan Kebudayaan. (2017). Panduan Penilaian oleb Pendidik dan Satuan Pendidikan Sekolah Menengah Pertama. Jakarta: Tim Direktorat Pembinaan SMP Kementerian Pendidikan dan Kebudayaan.

Khairiyah, N., \& Zen, E. S. (2017). Buku Guru Pendidikan Agama Islam dan Budi Pekerti Kelas X Revisi 2017. Jakarta: Kementerian Pendidikan dan Kebudayaan.

Kunandar. (2008). Guru Profesional Implementasi Kurikulum Tingkat Satuan Pendidikan (KTSP) dan Persiapan Menghadapi Sertifikasi Guru (1 ed.). Jakarta: PT. Raja Grafindo Persada.

Kusumawati, T. (2015, Juni). Pengembangan Instrumen Penilaian Ranah Afektif Mata Pelajaran Aqidah Akhlak. SMART, 1(1), 111-123.

Mantau, B. A. (2009, Mei). Pengukuran Ranah Afektif Mata Pelajaran Pendidikan Agama Islam Dalam Penilaian Berbasis Kelas. Pelangi Ilmu, 2(5), 115-128.

Muhson, A. (2004, Agustus). Meningkatkan Profesionalisme Guru: Sebuah Harapan. Ekonomi \& Pendidikan, 2(1), 90-98.

Pusat Kurikulum Depdiknas. (2004). Standar Kompetensi Mata Pelajaran Agama Islam Sekolah Dasar dan Madrasah Ibtidaiyyah. Jakarta: Depdiknas.

Rahmat, M. (2012, Mei 01). Profil Kompetensi Guru Agama MTs di Jawa Barat, Banten dan DKI Jakarta Dilihat dari Latar Belakang Biografis Guru. Diambil kembali dari dari Direktori File UPI: http:// file.upi.edu/Direktori/FP 
IPS/M_K_D_U/195801281986 121 -

MUNAWAR_RAHMAT/S1\%2

0METRIS $\% 20 \% 26 \% 20$ STATIS

TIK_Pen didikan/RISET-

LAPORAN_Kompetensi_Guru

_MTs_\%28Munawar\%29.pdf

Rini, S. (2014). Evaluasi Pembelajaran Pendidikan Agama Islam di Sekolah Menengah Atas. Bandung: Program Studi Ilmu Pendidikan Agama Islam Fakultas Pendidikan Ilmu Pengetahuan Sosial Universitas Pendidikan Indonesia.

Sugema, Sony. (2003-2004). Digital Quran versi 3.2. Diakses dari: http://www.geocities.com/sonys ugema2000/.

Suastra, I. W., \& Ristiati, N. P. (2016). Permasalahan Guru dalam Merancang dan Mengimplementasikan Penilaian Otentik dalam Pembelajaran Sains di SMP dan SMA. Seminar Nasional Riset Inovatif (Senari) Ke-4, (hal. 304-313).

Sudijono, A. (2016). Pengantar Evaluasi Pendidikan. Depok: PT Raja Grafindo Persada.

Sukmadinata, N. S. (2011). Metode Penelitian Pendidikan. Bandung: PT Remaja Rosdakarya.

Suyanto. (2010). Ilmu Pendidikan Islam. Jakarta: Kencana.

Wicaksono, Pamuji, T., Muhardjito, \& Harsiati, T. (2016). Pengembangan Penilaian Sikap dengan Teknik Observasi, Self Assessment, dan Peer Assessment pada Pembelajaran Tematik Kelas V SDN Arjowinangun 02 Malang. Jurnal Malang, 46.
Yusutria. (2017). Profesionalisme Guru dalam Meningkatkan Kualitas Sumber Daya Manusia. Curricula, 2(1), 38-46.

Zen, A. (2017). Penilaian Autentik Ranah Sikap pada Mata Pelajaran Pendidikan Agama Islam dan Budi Pekerti di SD Pilot Project Kurikulum 2013 Kabupaten Purbalingga. Tesis Magister Pendidikan. Institut Agama Islam Negeri Purwokerto.

\section{Peraturan Perundangan:}

Keputusan Menteri Agama Republik Indonesia Nomor 211 Tahun 2011 tentang Pedoman Pengembangan Standar Nasional Pendidikan Agama Islam pada Sekolah.

Peraturan Menteri Pendidikan dan Kebudayaan Nomor 23 Tahun 2016 tentang Standar Penilaian Pendidikan.

Peraturan Menteri Pendidikan Nasional Nomor 16 Tahun 2007 tentang Standar Kualifikasi Akademik dan Kompetensi Guru

Peraturan Pemerintah Nomor 55 Tahun 2007 tentang Pendidikan Agama dan Pendidikan Keagamaan.

Peraturan Pemerintah Nomor 32 Tahun 2013 tentang Standar Nasional Pendidikan.

Undang-Undang Nomor 14 Tahun 2005 tentang Guru dan Dosen.

Undang-Undang Republik Indonesia Nomor 20 Tahun 2003 tentang Sistem Pendidikan Nasional. 